\title{
Participative management in a public school of the periphery in Distrito Federal: A good way?
}

\author{
Magali Fátima Evangelista Machado \\ Secretaria de Estado de Educação do Distrito Federal \& Universidade Católica de Brasilia, \\ Brasilia, Brazil \\ magaliemachado@gmail.com \\ Olzeni Leite Costa Ribeiro \\ Educação Bàsica do Departamento do Distrito Federal, Brasilia, Brazil \\ Olzeni.ribeiro@gmail.com \\ Marcelino Tameirão-Machado \\ Ex-Gerente Executivo do Banco do Brasil S.A., Brasilia, Brazil \\ marcelinotmachado@gmail.com
}

\begin{abstract}
The present article has as an aim to assess the data of a school based education on the periphery area in Distrito Federal and that has been obtaining, according to the results of the National System of Basic Education Assessment (SAEB) and Prova Brasil, successive increase in the rank of the Index of Development of Basic Education (IDEB) in the years 2005, 2007 and 2009 and that works the participative management by means of discussions among the head of the school, teachers, students and their parents. The IDEB refers to the quality indicator, created by the federal government that integrates the aims of the Development Plan of Education (PDE). The IDEB is calculated based on the performance of students in institutional evaluations of Portuguese and Mathematics, data of failure, school dropout and rates of the students passing in examinations. As a main objective, the article has a proposal to present these results and discuss the proposed actions by the head of the school and the parents' participation, teachers, staff and students.
\end{abstract}

\section{Introduction}

Education plays a primordial role in the social, economic and cultural development of a country. The right to education has been established since 1948 in the Universal Declaration of Human Rights. This right is also reaffirmed in the Declarations of the Conferences of the United Nations, as Jomtien (1990) and Dakar (2000). According to the report of UNESCO (2008) denominated "Education for All", whose aim consists of evaluating the educational objectives of the international agreements in many countries such right is still far from being achieved. For Machado (2008), there are about 72 million children out of school all over the world. According to the author, the legislation alone does not guarantee the access to primary education, especially in the Sub-Saharan Africa, in the southeast of Asia and in some Arabic countries.

In Brazil, according to the data of 2009 School Census, there are 52,9 millions of students enrolled in the primary school that encompasses the following stages: nursery, preschool, primary school, secondary school, especial education, education for youth and adults and professional education. From this total, $86,3 \%$ are in state, counties or federal public

Journal of Contemporary Issues in Education, 2013, 8(1), pp. 4-14

ISSN 1718-4770 (C) 2013 University of Alberta

http://ejournals.library.ualberta.ca/index.php/JCIE 
schools and $13,6 \%$ in private schools. It means about 45 millions of children, teenagers and young students depend on the public power to have access to education while less than seven million students pay to study in some of the basic levels of teaching..

Therefore, it has to consider, then, that the universalization by itself does not constitute the final solution. Universalize, yes, but with social responsibility. Despite the divergent opinions to guarantee space in the public teaching in the country, from the nursery to the university has been constituting the background of the diverse educational sectors. In Guimaraes-Iosif's view (2009), the right to education in Brazil can not disregard the social and economic conditions of the poor students, the high indices of dropout and school failure, as well as the precarious learning of most of them. For the author, these are elements that denounce a right not asserted in its totality.

The school is seen, therefore, as a space of excellence from where it must emerge the discussions about the ways of conducting education in its multiple aspects, in the search for providing all the students with their peculiarities and socioeconomic and educative conditions. In addition to receiving the incumbency, also, of recreating its own organizational structure. But it is needed to recognize that schools are not the unique space for this discussion, it must have to be taken to the political and social settings of the nation too.

Finally, what is waited from the State and society is that the schools be responsible for the educative necessities of all the students indistinctly. In this sense, Santos (2010) points out that society has to articulate to define policies of equality and identity and reinforces that "we always have the right to be alike and that the difference makes us inferior; we have the right to be different whenever the equality of not characterizing us" (2010, p. 316).

The present article has as an aim to assess the data from a school based on the periphery in Distrito Federal and has been obtaining improvement in the Index of Basic Education Development (IDEB) and uses those indicators as signals of the discussions among the head, teachers, students and their parents.

\section{Influence of public policies in the educative scenario}

Before speaking of school and education, it is relevant to understand the appearance of the governance system, that Santos calls 'governação'. According to the author, this system "is conceived in itself as a post-state, assents in the voluntary cooperation selfactivated and self-regulated among actors and social relevant interests, operating in network" (Santos, 2010, p. 21). The author still highlights that the 'governação' is a genetical form modified of right and government. The governação turns resistant to what he defines as 'the two dangerous plagues' of society nowadays. The first plague, the popular pressures that can bring chaos to society and the second one is the capital accumulation that can cause unexpected changes of the game rules. Boaventura de Sousa Santos makes clear that the premise of the system of 'governação' is to incrust the society in the economy. He still highlights that it is the hegemonic system of the liberal globalization, even not being the unique, having its counterpoint, for example, in the policies that emerge from the World Social Forum.

In 1975, the authors Crozier, Huntigton and Watanuki, cited in Santos (2010) of the Trilateral Commission, published that the democracy was in crisis. And it was a crisis not for having less democracy, but for having more democracy. The legitimacy crisis had transformed into the crisis of governability. In the following decade, searching for building a

Journal of Contemporary Issues in Education, 2013, 8(1), pp. 1-3

ISSN 1718-4770 (C) 2013 University of Alberta

http://ejournals.library.ualberta.ca/index.php/JCIE 
new political-social regime, under the designation of Washington Consensus, the nations tried to get out of the governability crisis with the supremacy of the market law.

From 1986 to 1996, the rules of privatization, mercantilization and liberalization, in the highest degree of the neoliberalism, saw to emerge the civil organizations searching for supplying the necessities not received by the State, now as a concept of minimum State. It can not still be forgotten the narrow affinity between the State and the economic elites. Boneti (2007) remembers that in these relationships, the national interests and even the international ones appear as determinants. The author remembers that the policies of International Monetary Fund (IMF) and the World Trade Organization (WTO), try to impose their rules and their power in the process of elaboration and applicability of the public policies.

The formulation of educative policies, particularly in the countries of the periphery (and of the semi-periphery) of the world system, began to depend, increasingly, on the legitimization and the technical assistance of the international organizations, that allowed since the sixties, a rapid diffusion of the theories of modernization as in vogue in that period of euphoria, where the education turned into an obligatory instrument of the individual selfrealization, social progress and economic prosperity (HÚSEN, 1979). In what concerns the education as it is known since the middle of the seventies, relative issues under low levels of education of the Brazilian population came to be very problematic and continues until today.

The studies and their influences throughout the world were intensified after the creation of a vast system of international organizations of intergovernmental nature specialized in education, development and financing.

The United Nations Organization for Education, Science and Culture (UNESCO) acts in the areas of education, science and culture supported by the United Nations (ONU). In the area of development and economic cooperation according to the authors Ali Abdi and Shultz (2011), the Organization for Cooperation and Economic Development (OCDE), for example, provided a strong impulse to the internalization of educational problems all over the world.

In the financial field, in Silva's understanding (2002), the managers of the World Bank proposed indicators of institutional assessment used in the international ambit for the performance of the national educational systems. According to Scaf (2001), the World Bank has as a premise that education is an important instrument of "social promotion and economic increase and the poverty reduction in the countries in developing" (WORLD BANK, 1995, p, $\mathrm{xv})$.

In the end of the nineties, in Brazil, the World Bank presented a report that contained strategies of assistance to the Brazilian government by means of partnership to be achieved the universalization of primary education for all Brazilians until 2007 and that the quality of the education was assessed according to the market parameters. In the vision of Barroso (1995), the partnership of the Brazilian government with the World Bank led to the progressive expansion of the school to the whole layers and social groups that conducted to the consolidation of the samples of school organization and pedagogic organization capable of comprising increasingly a larger number of students. On the other hand, in the educational ambit, the focus on the speeches were, according to the author, how the "school would answer the challenge of teaching many as it were only one" (Barroso, 1995, p. 20).

According to Cunha (2011), the reforms adopted in the American continent, as a reply to the globalization, did not present the awaited results, mainly, they did not take in consideration the differences and specificities of the Latin American countries. In this sense, Cunha (2011) highlights that the educators need to contribute so that the changes in education do not occur from the center to the periphery, but that the discussions are part of quotidian of schools, universities and social movements, that is, from low to high. 
What is seen, therefore, is that in the arena of acting of international organisms, market and State appear the effective participation of the civil society and mainly of educators and instructors of educators.

\section{Revisiting the literature}

The educational reform implanted from the nineties, in Brazil, brought innovator definitions in what it concerns to the educational management, the professionalization of the teachers, a national curriculum and the evaluation of basic education. Brazil advanced a lot in the last twenty years and, in that period, several initiatives of the Brazilian government through the Ministry of Education and the Instituto Nacional de Estudos e Pesquisas Educacionais Anísio Teixeira (INEP) gave form to an efficient system of evaluation in all levels and modalities in the teaching, that is: National System of Evaluation of Basic Education (SAEB); National Exam of Secondary Teaching (ENEM); National Exam of Courses (ENC), known as Provão and, later, substituted for the National Exam of Performance of High Education (ENADE); National Exam of Certification of Young and Adult Competences (ENCCEJA); National System of Evaluation of High Education (SINAES); Prova Brasil and the Index of Development of Basic Education (IDEB).

All these systems highlight in their efficiency, while the policy of educative evaluation, insofar as they reveal an instrument that has been awakening the schools to check their performance before the others. To start with the LDBEN n ${ }^{\circ} 9.394$ (BRASIL, 1996), from September 20,1996, which establishes in its article 87 ( $\$ 3^{\text {rd }}$, incise IV), as a duty of the counties and the states and the Union, the integration of all establishments of primary teaching to the national system of school evaluation performance until the end of the Decade of Education (1997-2007).

For Locatelli (2002, p. 5) the evaluation systemic evaluation of the basic education was responsible for the objective of "monitoring the quality" and promoting the incorporation of the external evaluation in the quotidian with the support of improving the quality of teaching. However, the literature points to as an instrument favored to the quality the experiences focused on the learning and in the school. The institutional evaluations act as a strategic policy in the access to the interior of the schools, the 'black box' with the aim of knowing the internal dynamic underlying to the practice of the teachers. Countries as Cuba and Chile, Mexico, Peru, China, Spain, England, United States and France, among others, also use this strategy, trusting, the system nationals of evaluation, the responsibility of providing access to more effective form. (Castro, 2010, p. 148).

In Santo's understanding (2010), these reforms initiated in the Brazilian educational system in the beginning of the 90's, "apply" the administrative sample purely management, centered in the transposition of the relationships and market logic for the public management as a necessary alternative to the modernization and or the induction of improvement in the work of the State" (Santos, 2009), P. 19). These tendencies have been incorporated to the new forms of administration and management according to Castro (2010), that corroborate with the author when he points out the "necessity of improving the efficiency of the national systems and inciting the social and professional responsibility by the results of the education" (Ibid., p. 149).

Also, according to Castro (2010), there is no way of unknowing the contribution of

the evaluation systems as a tool that affect schools in the search for quality, in the perspective of trying to improve their indices. Even they allow a more general vision, insofar as the

Journal of Contemporary Issues in Education, 2013, 8(1), pp. 1-3

ISSN 1718-4770 (C) 2013 University of Alberta

http://ejournals.library.ualberta.ca/index.php/JCIE 
educative process does not generate immediate results and visible in a short run, even if they contribute to the policy that awakens the school from its comfort zone (CASTRO, 2010, P. 149).

The first, denominated ANEB - National Evaluation of Basic Education, which is most known as SAEB. The SAEB evaluation encompasses a sample of students from the public and private schools of the country, based on the rural and urban areas and enrolled in the fifth and ninth years of the primary school and also the third year of the secondary school. In these stratums, the results are shown to each State of the Federation, Region and Brazil as a whole.

The SAEB is an important subsidy for the monitoring of general policies of educational development. Based on the information collected by the system, the Ministry of Education (MEC) and the state and municipalities secretaries of education have to define actions turned to the correction of the distortions and debilities identified, in a way to guide the actions of technical and financial supply for the increase of the educational opportunities, efficiency and quality of the Brazilian educational system in their different levels.

The second evaluation from MEC was created in 2005 and is denominated ANRESC (National Evaluation of School Performance, but most known as Prova Brasil). This evaluation is applied to the students from the fifth to the ninth years of the public primary teaching, in the state, municipalities and federal schools, from the rural to the urban area in schools which have at least 20 students enrolled in the evaluated level. In this stratum, the exam is named Prova Brasil and offers results for the school, county, Unit of the Federation and country that are also used in the calculation of Index of Development of the Basic Education (IDEB). The IDEB is an indicator of the quality, with scores from zero to ten, combines the evaluation of the performance in exams with data of failure and dropout. Its calculation is based on the passing in an examination, obtained in the school census and the averages of performance obtained in the national evaluations: the SAEB, for the unities of the federation and country, and the Prova Brasil for the counties.

The Prova Brasil and SAEB use the same methodology, for being considered complementary evaluations. From 2007, the Prova Brasil and SAEB came to be operational in accordance with the National Institute of Studies and Educational Research Anísio Teixeira (INEP/MEC).

One of the relevant aspects of Prova Brasil is to offer to the whole participant schools a consistent diagnostic about the performance of their students, using the same metric of the SAEB evaluation. The results are comparable and allow that the school identifies its potentialities and fragilities in relation with the performance of its municipal, state, or in relation to its county, state, or even the country. As an important tool of school support, the Prova Brasil has contributed to improve its pedagogical project and raises the review of didactic practices that have been shown inefficient, even a timid form.

In the Freitas' view (2011), the use of indicators, based on the market laws, has a constrained and doubtful effect. It could not, with basis on the indicators, adopt consequences of high impact and unreal charges. Shaming schools, eliminating rights, firing teachers, paying teachers for merit, among others, should be substituted, in the author's vision, for a 'relational trust' based on respect, competence, consideration for the others and integrity. This negotiation does not imply lack of evaluation or regulation, but it should consider that the exams with the students can not be the only condition of public resources distribution. The author stresses that it is important to work with the teachers and managers and not against them.

Despite the system criticisms of evaluation and influences, are not even beneficial, from the policies of the international organisms, it can not disdain its worth as an instrument of comparison and systemic evaluation. What is waited is that based on the academic 
discussions and suitable forums, its sample can be developed from the governance with the participation of all, in special of society and its most relevant actors, the teachers and managers.

\section{Methodology}

In what concerns to the 'design of the research" understood in the Yin's perspective (1984) as a directed guide to the investigator in its process of collect, analysis and interpretation, the design of study was adopted in the simple case, having as a unit of analysis a unique organization (Yin, 1984). In this context, the school analyzed in the article refers to an institution of teaching that obtained the first place in the IDEB, in Brasilia, in the category $9^{\text {th }}$ year (The last years of the Primary Education) in the years 2005 and 2007 and fourth in the year 2009. The school is based on the periphery of Brasilia/DF, Brazil. Besides, the institutional evaluation data of Portuguese and Mathematics, generated by the SAEB related to the years 2005, 2007 and 2009 the school was visited three times. In the third visit a semistructured interview the head of the school gave an interview, that searched for getting actions effectively developed by the head of the school and teachers as well, that have been providing with the students to achieve the exit in their process of learning and also in the institutional evaluations.

\section{The school in social and economic context: Characteristics and perspectives}

The studied school in the present articles was named Escola $Z$ and is based on the south area in Distrito Federal, about $30 \mathrm{~km}$ from Brasilia. It is in the Administrative Region in Santa Maria. The Unit of Teaching receives students from the city Santa Maria, south and north, and also students from the south outskirt from Brasilia/DF. Nowadays, the Escola $Z$ has 1,278 students enrolled distributed in the morning and afternoon periods. In the morning period the classes are destined to the last years of primary school and the afternoon period teaches the initial years of primary school, so totalizing 41 classes and also the room of resources

The administrative equip of this teaching unit is composed of the head, vice-head, pedagogical supervisor and the administrative supervisor. In the school secretary, the boss of the secretary and two more assistants work. In the assistance career, the Escola Z counts on

four people responsible for the snack, four doormen, a general service and a clean worker and more nine workers from a tertiary enterprise. In the pedagogical sector, four pedagogical coordinators, an educational guidance, a monitor and 59 teachers from different areas of knowledge work.

The Escola $Z$ developed in 2011 projects that contributed to the dynamicity of its actions, awakening the students motivation in participating integrally in school activities. Some developed projects were entitle as the week of the family at school; the civic moment; the reading time; the knowledge fair; I read and write my future; chess; environment agenda; policy of promoting citizenship and peace culture among others.

The data were collected from the results of the evaluations of Prova Brasil of Portuguese in the years 2005, 2007 and 2009, according to the data from INEP. The Escola Z obtained the following indices shown in graphic 1 :

Journal of Contemporary Issues in Education, 2013, 8(1), pp. 1-3

ISSN 1718-4770 (C) 2013 University of Alberta

http://ejournals.library.ualberta.ca/index.php/JCIE 


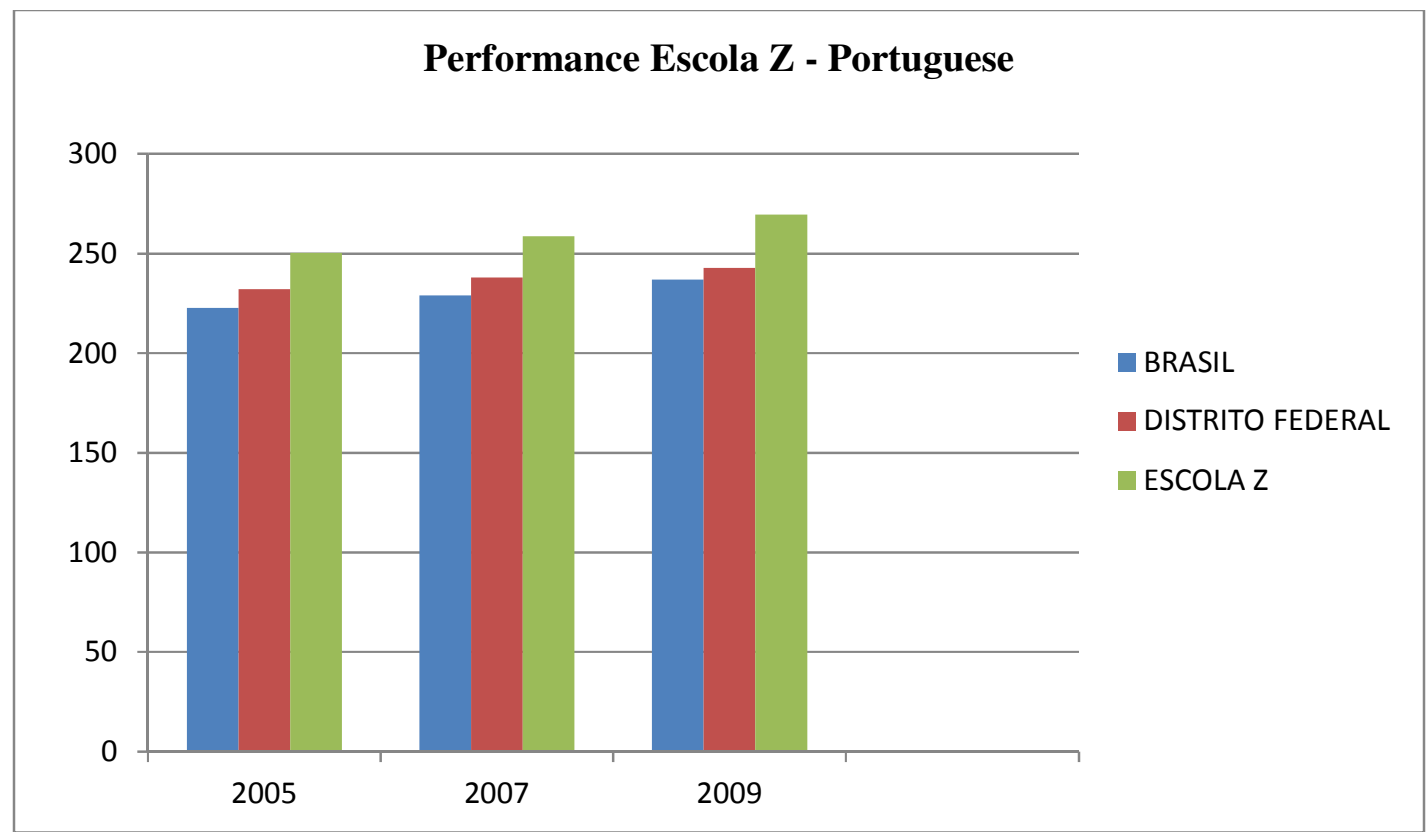

Graphic 1: Performance of Escola Z in the evaluations of Prova Brasil - Portuguese ${ }^{1}$

Source: Consulted data < http://sistemaprovabrasil2.inep.gov.br/resultados $>, 2011$.

The data were collected from the results of the evaluations of Prova Brasil of Mathematics in the years 2005, 2007 and 2009, according to the data from INEP. The Escola $Z$ obtained the following indices shown in graphic 2:

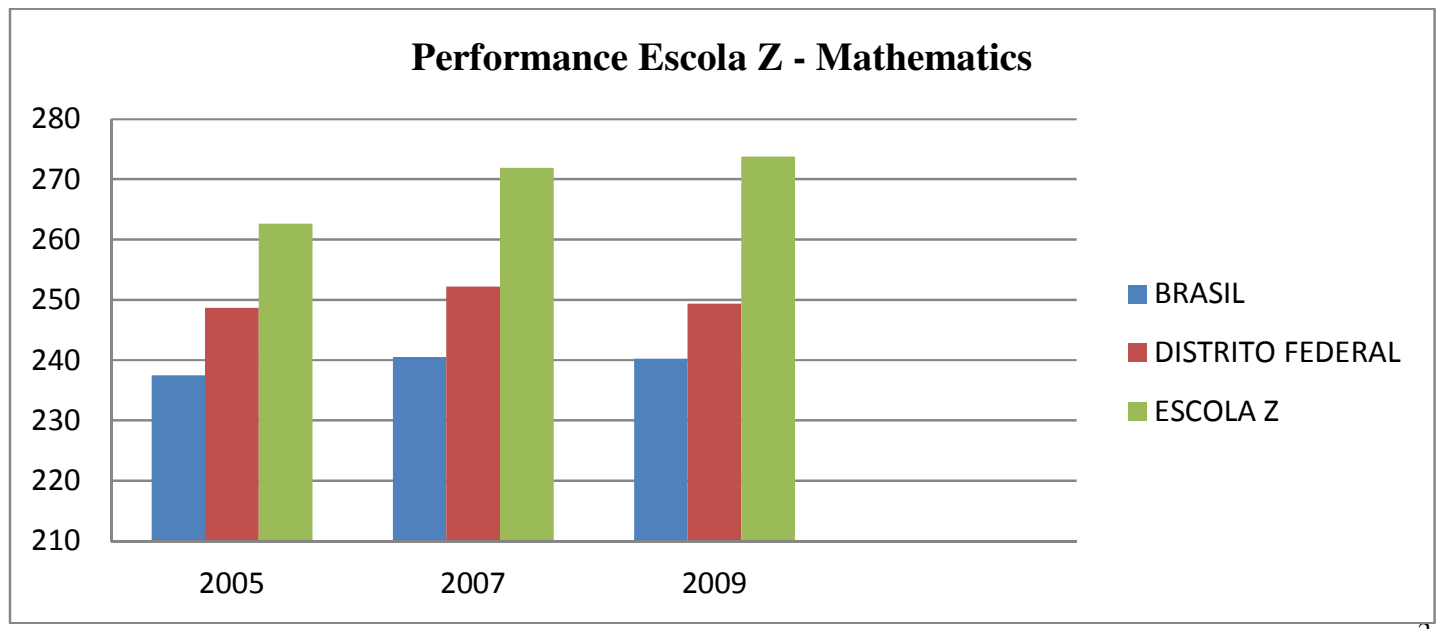

Graphic 2: Performance of Escola Z in the evaluations of Prova Brasil - Mathematics ${ }^{2}$

Source: Consulted data http://sistemaprovabrasil2.inep.gov.br/resultados $>, 2011$.

\footnotetext{
${ }^{1}$ The proficiency degree of Portuguese varies from level 125 to 325.

${ }^{2}$ The proficiency degree of Mathematics varies from level 125 to 350 .
} 
The data that consist in graphic 3 are results of IDEB in 2005, 2007 and 2009. The indicator of quality with grades from zero to ten adjusts to the evaluation of performance in the exams, with data of failure and dropout. Its calculation bases on the data of passing in a school exam, obtained in the school census and in the averages of performance obtained in the national evaluations: the SAEB for the units of the federation and for the country, and the Prova Brasil for the counties.

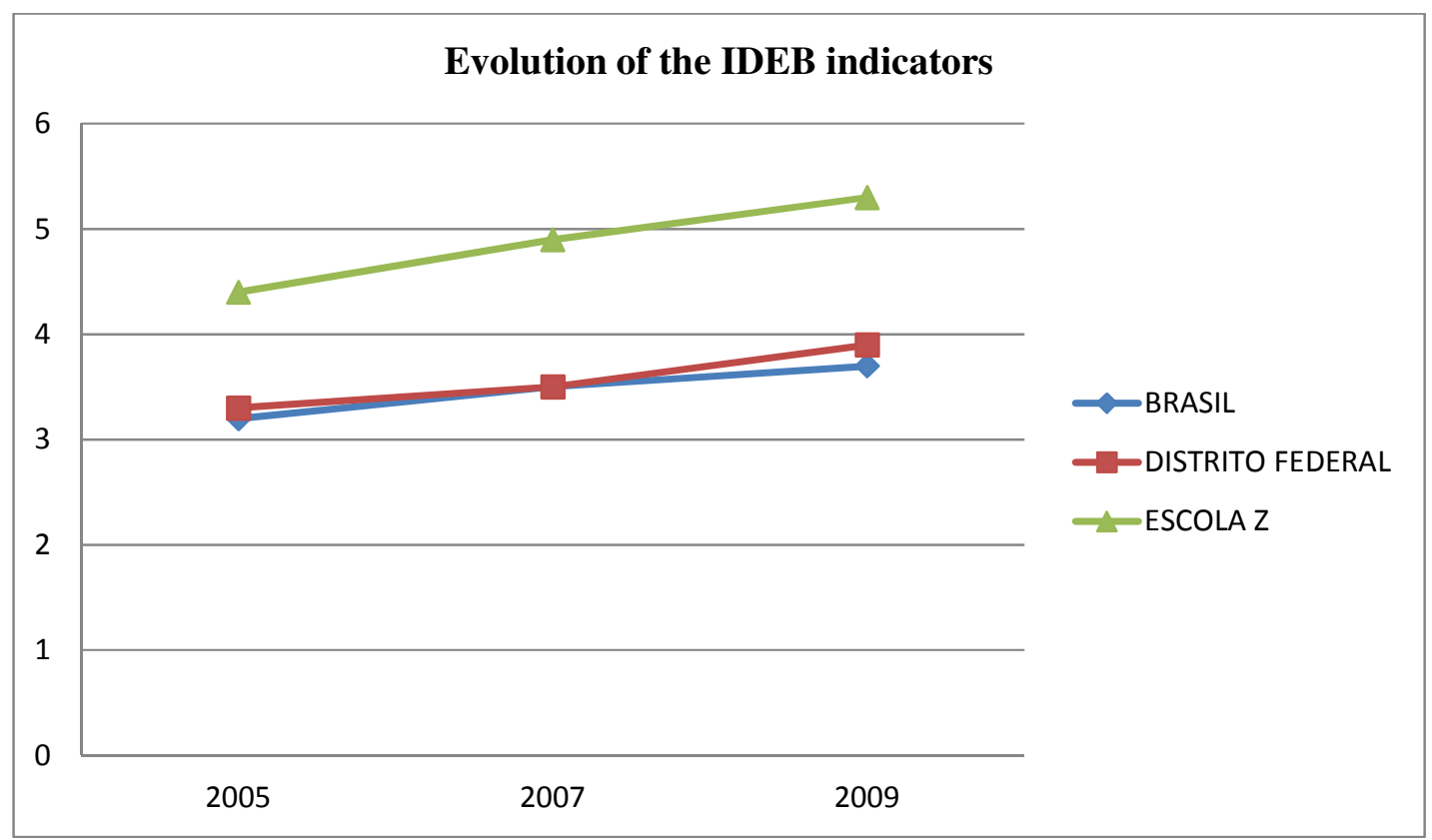

Graphic 3: Evolution of the indicators of the IDEB from Escola Z

Source: Consulted data http://ideb.inep.gov.br>, 2011.

It is perceived that the school development query, the unit of teaching has obtained indices higher than Distrito Federal and Brazil. The data corroborate the increase of events of the analysed period: from 4,4 in 2005, advanced on 5,3, in 2009. In this case, the school attained, in 2009, the prevailed goal for 2001, in the same teaching system in that $18 \%$ of the schools not even reached the minimum index determined for the public teaching in Distrito Federal in this stage of evaluation, which was 3,9. In this way, it is noted that the school indicators have been improving year after year and signalizing advances in the query 'school performance' in what it refers to students.

The school dynamics elaborated, managed and constructed by the own administrative and pedagogical equip inter-relate and seem to determine the efficacy in the production and concretization of the learning and their students.

For the head of the school, the main difference perceived by him is the participation of all the teachers, staff and the community (students and parents) in the formulation of the developed projects at school. As an example, in the Family Week at School, the parents participate intensely of conversations and workshops of companionship and could debate the course to be followed by the School Unit. 
As an element of the future research, it arises questions such as: what happened in these spaces of teaching and learning that take them to results so distinct from other similar schools? Considering the premise that the number of students in the classroom is generally compatible among the schools, the rules of the system methodize by the equity, the teachers' salaries are the same, could the pedagogical projects of this school, being submitted to the community skimmer and, therefore, elaborate in the collectivity explain these improvements in the indicators?

To explain this scenario there is no way to refer to the articulation of the two underlying dimensions in the practice of educational management: the efficiency and school efficacy. These concepts applied to the educational area seem to elucidate the schools movement towards the school success or failure of the students. By being receivers of the same incomes, the differential is in how to apply them properly, making more with less (efficiency), if it is considered that the state will never reach the necessity in its plenitude. By making the right choices and directed to the established aims, if they converge to the expectations and necessities of the community in consonance with the planned and executed strategies, the differential will be in reaching all the students indistinctly. Finally, the authors point to the higher is the degree of reaching the aims, the more the organization turns effective.

The systemic evaluations to be effective and efficient should be understood as a process, being regularly discussed with all educational, political and social segments in order to be able to direct the Brazilian education for the society which is desired, composed of conscious citizens, well informed with critical spirit and self-esteem.

\section{Final considerations}

Based on the indicator results from IDEB obtained by the school, it is noted that the defined aims by the school head and Secretary of State Education from Distrito Federal are in consonance with themselves. The article did not go deep, in this moment, in the causes and reasons of such syntony. Not even were discussed the validities of these indicators as an effective measure of quality education. However, it can be stressed that the effective students', teachers', school head's and civil society's participation demonstrated that this could be a way of reaching the so called dreamd and discussed improvement of the public education. These elements or factors allow the authors to believe that this school has been responsive to the necessities of the students from of the outskirt area of the federal capital, based on the IDEB results.

Remembering Paulo Freire (2004), the society will only change and the world transformed when the education is capable of changing people. If today as 'society' we make the option for life and not for death, the equity, living with the differences by the right and not for the injustice urges, then, to diminish the distance between what we say and what we do. 


\section{References}

Abdi, Ali A.; Shultz, Lynette. (2011) Governança Global e Política Educacional. Tema do VI Encontro Internacional, Universidade Católica de Brasília. In: LEUZE, Martens; RUSCONI. How to become an influential actor: the comparative turn in OECD education policy.

Barroso, J.(1995). Os Liceus. Organizações pedagógicas e administração, 1836-1960. Lisboa: Fundação Calouste Gulbenkian/JNICT.

Banco Mundial.(1995). Prioridades y estrategias para la educacion: estudio sectoria del Banco Mundial. Depart. de Educacion y Politicas Sociales.

Boneti, L. W. (2007). Politicas por dentro. 2. ed. Ed. Unijuí.

BRASIL. Lei de Diretrizes e Bases da Educação Nacional (LDBEN). (1996). Disponível em:

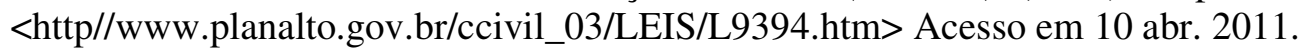
. Ministério da Educação. Índice de Desenvolvimento da Educação Básica (Ideb). Brasília, DF: MEC, 2007. Recovered from the internet 21 May, 2011 the: $<$ http://portal.mec.gov.br/ideb $>$

Castro, M. H. G. de. (2010). A Institucionalização da Política de Avaliação na Educação Básica no Brasil. In: Nos bastidores da educação brasileira. COLOMBO, S. S.; CARDIM, P. A. G. e Colaboradores. Porto Alegre: Artmed, 2010, pp.147-167.

Censo Escolar, 2009: as mudanças da Educação. Recovered from the internet 15 January, 2012 the: <http://educarparacrescer.abril.com.br/indicadores/censo-escolar-2009mudancas-educacao-517168.shtml

Cunha, Célio; Sousa, José Vieira de. \& Silva, Maria Abadia. (2011). Políticas públicas de educação na América Latina: lições aprendidas e desafios. Campinas, SP: Autores Associados.

Freire, P. (2004). Pedagogia do Oprimido. 38 ed. Rio de Janeiro: Paz e Terra.

Guimarães-Iosif, R. M. (2009). Educação, Pobreza e Desigualdade no Brasil: impedimentos para a cidadania global emancipada. 1. ed. Brasília: Líber Livro.

Húsen, T. (1979). L' école em question. Bruxelles: Pierre Mardaga. Recovered from the internet 6 February, 2012 the http://www.cairn.info/revue-francaise-de-pedagogie2008-3-page-5.htm> Acesso em 6 fev. 2012.

Instituto Nacional de Pesquisas Educacionais Anísio Teixeira. Prova Brasil. Recovered from the internet 30 May, 2011 the: <http://sistemaprovabrasil2.inep.gov.br/resultados $>$

. Resultados do Índice de Desenvolvimento da Educação Básica. Recovered from the internet 15 May, 2011 the: <http://www.inep.gov.br>

Machado, A. L (2008). Entrevista: A Educação ainda não é para todos. Recovered from the internet 11 April, 2011 the: <http://educarparacrescer.abril.com.br>

Locatelli, I. (2002). Construção para Avaliação de Larga Escala e Indicadores de Rendimento: O modelo SAEB. Estudos em Avaliação Educacional. Fundação Carlos Chagas.

Organização de Cooperação e Desenvolvimento Econômico (OCDE). (2010). Avaliação da Gestão de Recursos Humanos no Governo. Relatório da OCDE 2010. Recovered from the internet 15 May, 2011 the: <http://www.ouvidoriaservidor.gov.br>

SANTOS, B. S. (2010). A gramática do tempo: para uma nova cultura. 3. ed. São Paulo: Cortez.

Journal of Contemporary Issues in Education, 2013, 8(1), pp. 1-3

ISSN 1718-4770 @ 2013 University of Alberta

http://ejournals.library.ualberta.ca/index.php/JCIE 
Santos, M. M. B. (2010). Em busca de escolas eficazes: a experiência de duas escolas em um município da grande São Paulo e as relações escola-família. Faculdade de Educação da Universidade de São Paulo. São Paulo: Dissertação de Mestrado. Recovered from the internet 10 April, 2011 the:

http://www.teses.usp.br/index.php?option=com jumi\&fileid=17\&Itemid=160\&id=17A 20AB0AC01\&lang=fr $>$

Scaff, E. A. da S. (2001). Educação como estratégia política: a orientação dos organismos. Linhas Críticas. Brasília, v. 7, n. 12.

Silva, M. A da. (2002). Intervenção e Consentimento: a política educacional do Banco Mundial. Campinas, Autores Associados. São Paulo: FAPESP.

Unesco. (2005). Relatório de monitoramento de educação para Todos Brasil 2008: Educação para Todos em 2015, alcançaremos a meta? Brasília: Recovered from the internet 15 May the: <http://unesdoc.unesco.org/images/0015/001592/159294por.pdf>

Yin, R. K. (1984). Case study research: design and methods. London: Sage. 